\title{
Analisis Perancangan Sistem Informasi Administrasi Program Studi Pendidikan Teknologi Informasi dan Komunikasi
}

\author{
Dewi Sulistiyarini', Febrianto Sabirin ${ }^{2}$ \\ ${ }^{1,2}$ Program Studi Pendidikan Teknologi Informasi dan Komputer, Institut Keguruan dan Ilmu Pendidikan PGRI Pontianak, Indonesia
}

Keywords:
information system design;
database;
data flow;
interface

\begin{abstract}
ABSTRAK
Abstract: This study aims to determine the description of needs, data flow design, database design, and design of information systems administration interfaces PSTIK study program. The research used descriptive method with research form that is survey research. Research subjects are staff, leadership of study program and 60 students of study program. Data analysis technique is to describe the data collected. The results show that the administrative information system consists of seminars and theses, lecturer journals, incoming and outgoing letters, and reports that are tailored to functional requirements, interface needs, and performance needs. The flow of information system data consists of two entities ie students and staff. Students have 6 inflows and outflows, while staff has 10 inflows and outflows. The information system database consists of 16 entities with 8 interrelated relations. The information system interface is divided into two pages. The student page consists of 6 pages, while the staff page consists of three pages.
\end{abstract}

\section{Kata kunci:}

perancangan sistem informasi; basis data; aliran data; antarmuka

\begin{abstract}
Abstrak: Penelitian ini bertujuan untuk mengetahui gambaran kebutuhan, rancangan aliran data, rancangan basis data, dan rancangan antarmuka sistem informasi administrasi program studi P.TIK. Penelitian menggunakan metode deskriptif dengan bentuk penelitian yaitu penelitian survey. Subjek penelitian yaitu staf, pimpinan program studi dan 60 orang mahasiswa prodi P.TIK. Teknik analisis data yaitu mendeskripsikan data yang terkumpul. Hasil penelitian menunjukkan bahwa sistem informasi administrasi terdiri dari seminar dan skripsi, jurnal dosen, surat masuk dan keluar, serta laporan yang disesuaikan dengan kebutuhan fungsional, kebutuhan antarmuka, dan kebutuhan unjuk kerja. Aliran data sistem informasi terdiri dari dua entitas yaitu mahasiswa dan staf. Mahasiswa memiliki 6 aliran masuk dan aliran keluar, sedangkan staf memiliki 10 aliran masuk dan keluar. Basis data sistem informasi terdiri dari 16 entitas dengan 8 relasi yang saling berhubungan. Antarmuka sistem informasi dibagi menjadi dua halaman. Halaman mahasiswa terdiri dari 6 halaman, sedangkan halaman staf terdiri dari tiga halaman.
\end{abstract}

\section{Alamat Korespondensi:}

E-mail: dhewysulis@gmail.com (Dewi Sulistiyarini)

\section{Pendahuluan}

Teknologi merupakan hasil peradaban manusia yang bertujuan untuk memudahkan kehidupan manusia. Perkembangan teknologi tersebut tentunya telah memberikan pengaruh yang besar bagi kehidupan manusia baik dalam kehidupan pribadi maupun bermasyarakat. Teknologi yang telah digunakan secara luas pada hakikatnya digunakan untuk membantu manusia guna mencapai efisiensi dan efektifitas kerja. Efisiensi kerja dapat dilihat dari penggunaan sumber daya dalam mengerjakan suatu pekerjaan. Semakin sedikit sumber daya yang digunakan maka pekerjaan tersebut tentu semakin efektif. Selain meningkatkan efisensi, teknologi juga membantu efektivitas dalam bekerja yang dapat dilihat dari banyaknya pekerjaan yang dapat diselesaikan. Semakin banyak pekerjaan yang diselesaikan maka efektivitasnya semakin tinggi.

Kemajuan teknologi pada masa kini telah berkembang dengan sangat pesat. Kemajuan ini dapat dilihat dari banyaknya penemuan (invention) maupun inovasi (inovation) yang ada. Penemuan berarti proses pembuatan teknologi yang benar-benar baru yang belum ada sebelumnya, sedangkan inovasi merupakan proses memperbarui teknologi yang sudah ada guna memperbaiki kelemahan teknologi ataupun menambahkan fungsi pada teknologi tersebut. Baik penemuan maupun inovasi teknologi telah menimbulkan pengaruh pada masyarakat sehingga terjadi perubahan diberbagai bidang kehidupan. 
Diantara berbagai teknologi yang terus berkembang, salah satu yang paling menonjol pada masa ini adalah teknologi pada bidang informasi. Teknologi informasi merupakan segala bentuk teknologi yang membantu manusia dalam membuat, menyimpan, ataupun menyebarkan suatu infomasi. Meskipun secara harfiah teknologi informasi dapat berupa buku, catatan, dan sejenisnya, namun dengan perkembangan zaman teknologi informasi lebih dikaitkan dengan peralatan yang mampu melakukan komputasi dan komunikasi dengan kecepatan yang tinggi seperti komputer dan internet.

Peran informasi sudah menjadi bagian penting dalam kehidupan manusia sejak zaman dahulu. Informasi yang merupakan hasil pengolahan suatu data atau fakta telah terbukti membantu manusia dalam mengambil keputusan. Pada dasarnya manusia adalah pemerosesan data terbaik, karena manusialah yang menentukan apakah suatu data akan menjadi informasi ataukah tetap menjadi data. Namun dalam perkembangan saat ini, data yang ada berjumlah sangat masif sehingga manusia memerlukan pemrosesan yang cepat dan pemilhan yang tepat terhadap data-data yang ada. Disinilah peran teknologi informasi mengolah data-data yang ada menjadi informasi yang nantinya berguna bagi manusia.

Melihat sentralnya peran informasi, maka tidak heran teknologi informasi merupakan suatu kebutuhan baik untuk pribadi, bisnis, organisasi, pemerintahan, dan tidak terkecuali lembaga pendidikan. Lembaga pendidikan merupakan penyedia jalur pendidikan baik formal maupun nonformal. Lembaga pendidikan tentunya memiliki karakteristik yang khas yang membedakan dengan bentuk organisasi lainnya. Dalam lembaga pendidikan selain fungsi utamanya sebagai penyedia layanan pendidikan tentunya perlu memanajemen sumber daya yang dimilikinya.

Teknologi informasi pada lembaga pendidikan umumnya sangat diperlukan pada dua bagian ini. Pada bagian pendidikan teknologi informasi berfungsi untuk membantu proses belajar mengajar sementara pada bagiam manajemen teknologi informasi membantu dalam mengatur sumber daya yang dimiliki lembaga tersebut. Penggunaan teknologi informasi pada bagian pendidikan dapat diterapkan dengan penggunaan ujian berbasis komputer (computerbased test), pembelajaran berbantuan komputer (computer aided learning), pembelajaran berbasis komputer (computer based learning), hingga penggunaan pembelajaran jarak jauh (distant learning). Sementara untuk manajamen, teknologi informasi dapat diterapkan dengan penggunaan sistem manajemen akuntansi, sistem informasi akademik, sistem manajemen barang, sistem informasi kepegawaian, dan lain sebagainya.

Institut Keguruan dan Ilmu Pendidikan Persatuan Guru Republik Indonesia (IKIP-PGRI) Pontianak sebagai salah satu lembaga pendidikan tinggi sejatinya telah menerapkan teknologi informasi baik dalam pendidikan maupun dalam manajemennya. Salah satu bentuk penerapan teknologi informasi yang wajib digunakan oleh lembaga pendidikan tinggi yaitu yaitu sistem informasi akademik (Permendikbud, 2013: 4). Penelitian tentang pentingnya sistem informasi manajemen sendiri telah dilakukan oleh Breiter \& Light (2006: 206) yang menyatakan bahwa akuntabilitas memberikan dorongan dalam pengujian data dengan data lainnya dalam pengambilan keputusan sehingga menumbuhkan minat dalam sistem informasi manajemen dalam pendidikan. Sistem informasi sejatinya merupakan kombinasi dari teknologi informasi dengan aktivitas orang-orang yang menggunakan teknologi informasi tersebut. Meskipun demikian tentunya masih terdapat bagian-bagian dari IKIP-PGRI Pontianak yang masih perlu ditingkatkan efisiensi dan efektivitasnya sehingga memerlukan penerapan teknologi informasi yang tepat.

Salah satu penerapan teknologi yang sangat diperlukan adalah di Program Studi yang terdapat di IKIP-PGRI Pontianak. Program studi memiliki peranan penting karena merupakan jembatan antara dosen dengan mahasiswa, mahasiswa dengan mahasiswa, dosen dengan dosen, serta dosen dengan fakultas/rektorat. Program studi juga berperan dalam memantau kinerja dari dosen dan kegiatan mahasiswa. Melihat banyaknya tugas dan fungsi Program Studi maka penggunaan teknologi informasi yang tepat tentunya akan sangat membantu tugas dan fungsi tersebut.

Kenyataan di lapangan, tugas dan fungsi ini belumlah berjalan dengan maksimal. Hal ini dapat dilihat pada Program Studi Pendidikan Teknologi Informasi dan Komputer (P.TIK) yang merupakan salah satu program studi yang ada di IKIP-PGRI Pontianak. Berbagai kendala masih dihadapi Program Studi P.TIK dalam memanajemen tugas dan fungsi program studi. Hal ini dikarenakan adanya ketergantungan yang besar pada staf yang menjalankan tugas dan fungsi yang diembankan kepada staf tersebut, sedangkan jumlah staf program studi hanya ada satu orang dan selebihnya adalah dosen yang dibantukan untuk mengerjakan tugas dan fungsi program studi. Tugas dan fungsi program studi semakin tidak efektif karena staf tidak selalu berada ditempat yang mengakibatkan mahasiswa harus menunggu dengan tidak jelas, selain itu dosen yang diperbantukan juga memiliki tugas utama yaitu mengajar, meneliti, dan pengabdian pada masyarakat yang akhirnya tidak bisa selalu berada di tempat.

Untuk mengatasi permasalahan yang ada di program studi khususnya Program Studi P.TIK dapat menerapkan teknologi informasi yang melibatkan peran serta aktif penggunanya yang dalam hal ini mahasiswa ataupun dosen. Sebagai contoh apabila ingin mengajukan sidang skripsi atau seminar skripsi, 
mahasiswa dapat menginput data-data yang diperlukan sehingga tidak perlu menunggu staf yang menginputkan data-data tersebut. Staf cukup bertugas memeriksa apakah data-data yang diinputkan telah benar atau tidak, jika telah benar maka dapat dilanjutkan, apabila tidak maka mahasiswa harus memasukkan data sesuai dengan kebutuhan. Sesuai dengan penelitian Abraham, Junglas, Willis (2010) bahwa untuk mengatasi permasalahan organsisasi dapat menggunakan pendekatan Service Oriented Architectures (SOA) berbasis web yang mudah digunkan dan meningkatan kemampuan sumber daya. Penggunaan teknologi informasi seperti ini tentunya akan menciptakan kinerja yang lebih efisien dan efektif pada Program Studi P.TIK.

Teknologi informasi seperti gambaran tersebut dapat diaplikasikan dengan sistem informasi berbasis internet. Internet digunakan karena pengguna dapat menginputkan data dimana saja dan kapan saja selama pengguna memiliki akses ke internet. Untuk masalah akses internet, saat ini hampir semua orang telah memiliki telepon pintar ataupun perangkat bergerak lainnya sehingga sangat mudah terhubung dengan internet. Selain itu, internet merupakan teknologi yang sudah umum saat ini, orang-orang pada saat ini sudah sangat terbiasa menggunakan internet.

Penelitian lain dilakukan oleh Duan \& Zhang (2007: 218) menyatakan bahwa analisis, desain, pengembangan, dan manajemen sistem informasi haruslah berorientasi pada orang mulai dari awal sistem dibuat hingga hasil akhir sistem. Dalam upaya mengembangkan suatu teknologi diperlukan analisis kebutuhan yang memadai. Sesuai dengan pendapat dari Pressman (2010: 319) dalam tahap analisis kebutuhan akan dilakukan proses penemuan, perbaikan, pemodelan, dan spesifikasi. Hal ini bertujuan agar teknologi yang dihasilkan memiliki kualitas yang memadai dan sesuai dengan kebutuhan dari pengguna teknologi tersebut.

Analisis kebutuhan yaitu tahapan awal yang dilakukan dalam mengembangkan perangkat lunak. Analisis kebutuhan merupakan bagian dari model data dan dilaksanakan bersamaan dengan diagram Entity Relationship. Analisis kebutuhan merupkaan suatu proses yang dilaksanakan untuk mendapatkan informasi, spesifikasi tentng perangkat lunak yang akan dikembangkan. Tahapan yang dilakukan dalam analisis kebutuhan perangkat lunak, yaitu mempelajari dan memahami persoalan, mengidentifikasi kebutuhan pemakai, mendefinisikan kebutuhan perangkat lunak (kebutuhan fungsional, kebutuhan antarmuka, kebutuhan unjukkerjaa), membuat dokumen spesifikasi kebutuhan perangkat lunak, mereview kebutuhan. Analisis kebutuhan dipengaruhi oleh tiga faktor, yaitu lengkap, detail, dan benar. Yang artinya, kebutuhan data dan informasi yang diinginkan harus berasal dan sesuai dengan keinginan dari klien.

Tahap perancangan suatu teknologi seringkali dianggap sebagai tahap yang sederhana, tetapi hal ini sangatlah tidak benar. Dalam tahap perancangan diperlukan komunikasi yang tepat antara pengguna dengan perekayasa agar didapatkan informasi yang benar. Pada tahap ini kemungkinan terjadinya kesalahan informasi dan kesalahan interpretasi yang tinggi akibat dari ambiguitas informasi sangatlah mungkin terjadi. Untuk itulah suatu perancang teknologi harus mampu menentukan fungsi, kinerja, dan batasan yang jelas agar teknologi yang dihasilkan tepat guna, tepat sasaran, dan tepat waktu.

Tahap perancangan sistem informasi dimulai dengan melakukan perancangan terhadap antarmuka sistem informasi. Perancangan Antarmuka memiliki beberapa tipe berdasarkan kebutuhan pengguna, yaitu antarmuka berbahasa alamiah, antarmuka pertanyaan dan jawaban, menu-menu, antarmuka formulir isian, dan antarmuka bahasa perintah (Kendall \& Kendall, 2003: 197) .

Untuk menggambarkan informasi yang telah didapat salah satunya dapat menggunakan Unified Modeling Language (UML). Menurut penelitian Zheng, Feng, \& Zhao (2014: 129) membuktikan bahwa UML dapat menggambarkan informasi antara pengguna, pengembang, desainer, dan manajemen dengan efisien. UML dapat meningkatkan kolaborasi dan dapat meningkatkan keberhasilan pembuatan perangkat lunak.

Selain menggunakan UML, perancangan sistem informasi dapat menggunakan Data Flow Diagram (DFD). Data flow diagram (DFD) merupakan suatu diagram yang menggambarkan arus sistem menggunakan notasi - notasi. DFD digunakan dalam melakukan analisa dan perancangan sistem sehingga mudah dipahami oleh pemakai maupun programer. DFD sering disebut dengan bubble chart, bubble diagram, model proses, dan diagram arus kerja.DFD digunakan sebagai alat komunikas antara pemakai dan sistem analis, selain itu DFD juga digunakan untuk menggambarkan batasan otomasi sebagai pengembangan alternatif.

Tahap perancangan selanjutnya adalah perancangan tentang basis data yang akan digunakan dalam sistem informasi. Entity Relationship Diagram (ERD). Entity relationship diagram (ERD) merupakan gambaran tentang struktur basis data yang digunakan dalam membangun sistem informasi. ERD merupakan metodologi utama dalam menciptakan pemodelan data. Metodologi dalam ERD menurut Simarmata (2007: 98) yaitu menentukan entitas, menentukan relasi, gambar ERD sementara, isi kardinalitas, tentukan kunci utama, gambar ERD berdasar kunci, menentukan atribut, pemetaan atribut, gambar ERD dengan atribut, periksa hasil. 


\section{Metode}

Penelitian menggunakan pendekatan kualitatif. Metode penelitian yang digunakan yaitu metode deskriptif dan bentuk penelitian yaitu survey. Menurut Cohen dan Nomion (1982 dalam Sukardi, 2012: 193) mengatakan bahwa:

Survey gathers data at a particular point in time with the intention of a) describing the nature of existing conditions, or b) identifying standards againts which existing condition can be compared, or c) determining the relationships that exist between specific events.

Penelitian dilaksanakan pada tahun akademik 2016/2017 di Program Studi P.TIK IKIP-PGRI Pontianak. Subjek penelitian tentang sistem informasi akademik program studi PTIK yaitu staf, pimpinan program studi, dan mahasiswa yang berada di lingkungan prodi P.TIK.

Teknik pengumpulan data berupa observasi, wawancara, dan angket. Pengumpulan data mengenai kegiatan sehari-hari dari staf program studi diamati dengan menggunakan panduan observasi. Hal ini berarti peneliti berada disekitar staf yang diamati. Instrumen yang digunakan dalam observasi data berupa pedoman observasi terbuka. Pengumpulan data mengenai kebutuhan fungsi sistem, antarmuka sistem, dan performa sistem didapatkan melalui wawancara mendalam kepada staf dan pimpinan Program Studi P.TIK. Wawancara digunakan untuk mengetahui permasalahan dan batasan sistem secara mendalam. Instrumen wawancara yang digunakan adalah pedoman wawancara mendalam. Berbeda dengan pedoman wawancara pada wawancara terstruktur pada wawancara mendalam pewawancara dapat mengembangkan pertanyaan berdasarkan jawaban dari informan.Pengumpulan data mengenai kebutuhan fungsi sistem, antarmuka sistem, dan performa sistem didapatkan melalui angket kepada mahasiswa Program Studi P.TIK.Jenis angket yang digunakan adalah angket terbuka dimana responden diberi kesempatan untuk memberi jawaban secara bebas menggunakan kalimatnya sendiri.

Data diperoleh dengan menggunakan berbagai macam teknik pengumpulan data yang dilanjutkan dengan melakukan analisis data. Proses analisis data pada penelitian ini meliputi tahapan koleksi data (data collection), yaitu dengan mengumpulkan data dari hasil observasi, wawancara, dan angket yang diperoleh peneliti dari subyek penelitian. Tahapan penyederhanaan data (data reduction), yaitu proses pemilihan, penelaahan, dan penyederhanaan data yang muncul dalam observasi, wawancara, dan angket sehingga diperoleh hal-hal pokok yang berkaitan dengan fokus penelitian. Tahapan penyajian data (data display), yaitu penyusunan hal-hal pokok dan pola yang sudah dirangkum secara sistematis dan logis. Hal ini dimaksudkan agar mempermudah peneliti untuk melihat gambaran secara keseluruhan atau bagian-bagian tertentu dari data penelitian. Pada tahap ini hasil observasi dan wawancara diorganisasikan dalam bentuk sajian deskriptif berupa narasi, sedangkan data dari angket diorganisasikan dalam bentuk sajian tabel dan yang disortir menurut kriteria atau kategori yang sejenis untuk ditampilkan agar selaras dengan fokus penelitian. Tahapan penarikan kesimpulan (conclusion drawing), yaitu upaya untuk mencari makna dari data yang dikumpulkan dan disajikan dengan mencari pola, tema, hubungan, persamaan, perbedaan untuk memantapkan kesimpulan yang lebih rinci.

\section{Hasil dan Pembahasan}

Administrasi Program Studi P. TIK bertujuan untuk memberikan pelayanan kepada stake holder dari Program Studi P. TIK. Secara umum administrasi program studi P.TIK ditujukan kepada empat pengguna layanan yaitu: 1) mahasiswa; 2)dosen; 3) pimpinan prodi; dan 4) fakultas serta lembaga IKIP-PGRI Pontiana. Dari kelima komponen tersebut, komponen mahasiswa merupakan stakeholder Program Studi P.TIK yang paling sering interaksi dengan staf administrasi program studi. Pelayanan terkait skripsi merupakanmodel pelayanan yang paling panjang pengurusannya dan dapat dibagi menjadi tiga komponen besar yaitu: 1) menentukan pembimbing dan pengajuan judul penelitian; 2) Seminar; dan 3) Skripsi. Sementara terkait dosen terdapat dua kegiatan yang wajib dilakukan program studi P.TIK yaitu: 1) Penjadwalan; dan 2) Jurnal Mengajar Dosen. Komponen pimpinan program studi, fakultas, dan lembaga IKIP-PGRI Pontianak terkait laporan pelaksanaan administrasi program studi. Komponen tambahan dalam administrasi prodi P.TIK adalah terkait dengan surat-menyurat baik untuk mahasiswa, dosen, fakultas, lembaga, ataupun lainnya.

Berdasarkan wawancara dan observasi terkait seminar dan skripsi diketahui bahwa di Program Studi P.TIK menggunakan program work sheet untuk membantu pendataan. Akan tetapi terlihat bahwa datadata yang dimasukkan oleh staf input dan staf checking terdapat beberapa redudansi. Hal ini dapat dilihat pada staf input perlu meminta beberapa kali data mengenai NIM, Nama, Pembimbing sementara pada staf checking mahasiswa masih diminta KTM, KRS, Bukti Pembayaran. Adapun data-data yang dibutuhkan staf input terkait seminar dan skripsi terdiri dari identitas mahasiswa, judul, pembimbing, tempat penelitian, 
waktu dan tempat pelaksanaan seminar/sidang, penyanggah dosen dan mahasiswa, notulis, dan penguji sidang. Sementara untuk staf checking membutuhkan data-data yang terdiri dari kartu tanda mahasiswa, bukti-bukti pembayaran, sertifikat kegiatan wajib, surat keputusan, kartu rencan dan hasil studi, transkrip nilai, dan surat-surat penelitian.

Untuk kegiatan Program Studi P.TIK terkait dengan jurnal mengajar dosen tidak memerlukan banyak data. Data mengenai jurnal mengajar dosen diambil dari jurnal mengajar dosen yang terdiri dari data dosen (nama, NIDN), data mata kuliah (kode, nama, dan SKS), tanggal, dan ruangan. Sementara itu, untuk kegiatan surat masuk dan surat keluar merupakan kegiatan.

Program Studi P.TIK yang belum dilakukan pendataan dengan baik. Meskipun belum dilakukan pendataan, berdasarkan surat masuk dan surat keluar dapat diketahui beberapa komponen yang diperlukan untuk data surat masuk dan surat keluar yaitu: asal/tujuan, nomor surat, tanggal surat, dan perihal. Kegiatan terakhir yaitu terakit pelaporan di program studi P.TIK masih bersifat insidentil, namun berdasarkankegiatan-kegiatan dapat diketahui beberapa laporan rutin yang dapat dibuat yaitu terkait laporan seminar, sidang, kehadiran dosen, dan surat-menyurat.

Berdasarkan data-data yang diperlukan untuk membangun sistem informasi administrasi program studi P.TIK maka dapat dibentuk gambaran model relasional system. Gambaran tersebut dapat dilihat pada gambar 1.

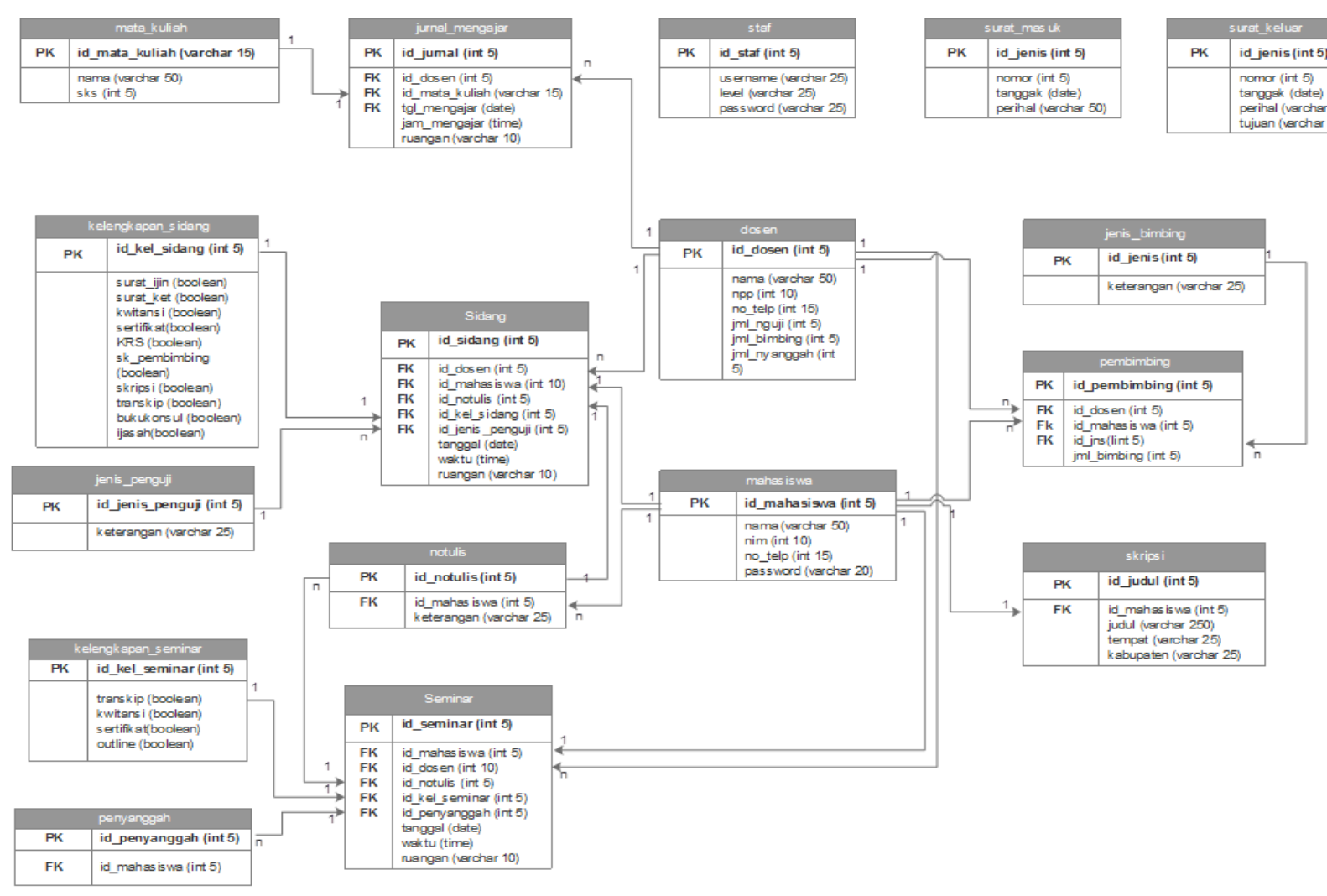

Gambar 1. Model Relasional Sistem Informasi Administrasi Program Studi P.TIK

Berdasarkan kegiatan administrasi di Program Studi P.TIK diketahui bahwa terdapat beberapa entitas dalam kegiatan administrasi tersebut. Entitas tersebut adalah mahasiswa, staf, pimpinan dan dosen. Dari kegiatan administrasi program studi P.Tik maka dapat dibuat aliran data yang mengalir dalam kegiatan administrasi tersebut. Adapun diagram aliran data pada sistem inti (fundamental system model) tersebut dapat dilihat pada gambar 2 . 


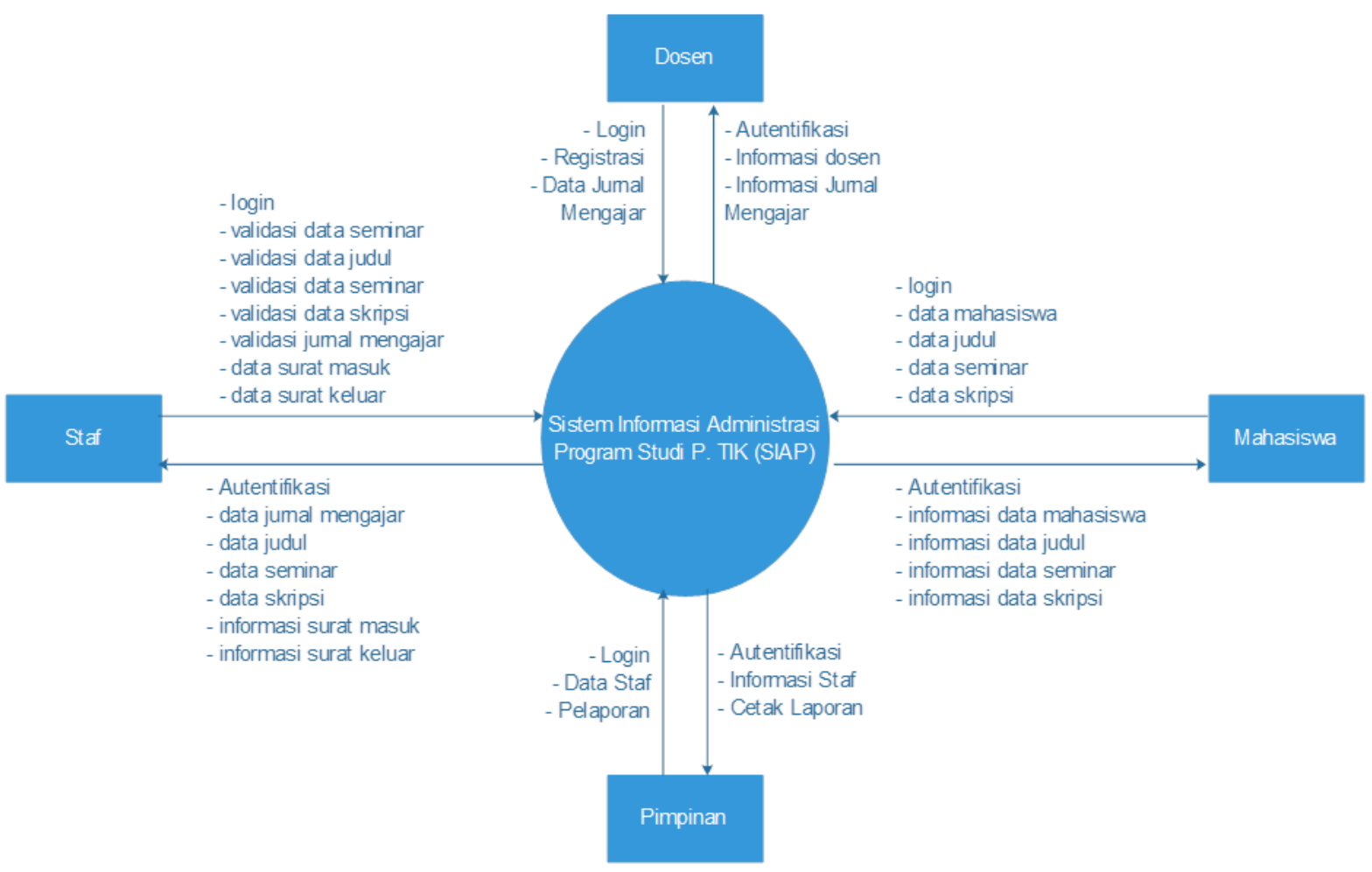

Gambar 2. Data Flow Diagram Sistem Informasi Administrasi Program Studi P.TIK

Berdasarkan gambar fundamental system model tersebut diketahui bahwa setiap entitas memiliki aliran data yang masuk ke sistem atau yang dihasilkan dari sistem. Untuk entitas mahasiswa dapat melakukan kegiatan seperti registrasi, login, mengelola data mahasiswa, mengelola data judul skripsi, mengelola data seminar, dan mengelola data skripsi. Untuk entitas dosen dapat melakukan kegiatan seperti login, registrasi, dan mengisi jurnal mengajar. Untuk entitas staf dapat melakukan kegiatan seperti pemeriksaan jurnal mengajar dosen, pemeriksaan judul mahasiswa, pemeriksaan kelengkapan seminar mahasiswa, pemeriksaan kelengkapan skripsi mahasiswa, mengelola surat masuk dan keluar. Entitas pimpinan dapat melakukan kegiatan seperti login, mengelola data staf, dan mengelola pelaporan.

Adapun aliran data untuk Sistem informasi Program Studi P. TIK mengalir dari berbagai entitas ke sistem yang dilanjutkan ke entitas lain ataupun kembali ke entitas itu sendiri. Aliran data dari entitas mahasiswa yang mengalir ke sistem yaitu login, data mahasiswa, data judul, data seminar dan skripsi. Untuk data login dan data mahasiswa, sistem akan langsung memberikan keluaran berupa autentifikasi login dan informasi data mahasiswa, sementara data lain akan diteruskan dari sistem ke entitas staf. Aliran data dari entitas dosen yaitu: login, registrasi, dan data jurnal mengajar. Sama seperti entitas mahasiswa, data login dan registrasi, sistem akanlangsung memberikan keluaran berupa autentifikasi dan informasi dosen, sementara data jurnal mengajar akan diteruskan sistem ke entitas staf. Aliran data dari entitas staf yang mengalir dari sistem berasal dari entitas dosen dan mahasiswa seperti data jurnal mengajar, data judul, data seminar, dan data skripsi. Entitas staf selanjut akan mengalirkan data berupa validasi data-data yang dimasukkan oleh dosen dan mahasiswa yang selanjutnya akan diteruskan ke entitas mahasiswa dan dosen. Selain data yang mengalir dari entitas lain, untuk entitas staf juga memiliki aliran data yang masuk dan keluar dari sistem yaitu login, data surat masuk dan keluar dengan keluaran berupaa autentifikasi, informasi surat masuk dan keluar. Entitas terakhir yaitu: entitas pimpinan mengalirkan data berupa login, data staf, dan pelaporan serta memiliki aliran data keluar dari sistem yaitu autentifikasi, informasi staf, dan cetak laporan.

Kebutuhan sistem yang akan dibangun digunakan untuk memberikan gambaran akan kebutuhan sistem yang sesuai dengan pengguna sistem. Untuk mengetahui kebutuhan sistem informasi yang akan dibangun maka melibatkan para pengguna akhir dari sistem yang terdiri dari mahasiswa, staf, dosen, dan pimpinan program studi. Terdapat tiga aspek dalam pengumpulan kebutuhan sistem yaitu: 1) kebutuhan fungsional; 2) kebutuhan antarmuka; dan 3) kebutuhan unjuk kerja. Adapun hasil kebutuhan sistem dapat dilihat pada tabel 1 . 
Tabel 1. Hasil Kebutuhan Sistem Informasi Administrasi Program Studi P.TIK

\begin{tabular}{|c|c|c|}
\hline Kebutuhan & Aspek & Keterangan \\
\hline \multirow[t]{3}{*}{ Fungsional } & Input & $\begin{array}{l}\text { Sistem berupa website, perlu memeriksa/validasi input, } \\
\text { membatalkan proses input, dan mendapatkan nomor } \\
\text { referensi }\end{array}$ \\
\hline & Penyimpanan & $\begin{array}{l}\text { Sistem mempunyai fitur auto save, peringatan sebelum } \\
\text { keluar sistem, dan session antara } 1-3 \text { jam }\end{array}$ \\
\hline & Pelaporan & $\begin{array}{l}\text { Sistem menyediakan fitur print preview, mengirimkan via } \\
\text { email, menghasilkan file dengan format PDF }\end{array}$ \\
\hline \multirow[t]{2}{*}{ Antarmuka } & Sistem & $\begin{array}{l}\text { Sistem menggunakan fasilitas internet dan sebagian besar } \\
\text { pengguna telah terbiasa memasukkan data pada website. } \\
\text { Sistem digunakan untuk smartphone, laptop, dan PC. } \\
\text { Dibutuhkan panduan untuk memasukkan dokumen dan } \\
\text { gambar. }\end{array}$ \\
\hline & Perangkat Lunak & $\begin{array}{l}\text { Sistem memerlukan petunjuk yang jelas terkait ikon, } \\
\text { navigasi, dan feedback dapat diberikan tiap perpindahan } \\
\text { halaman memasukan data. }\end{array}$ \\
\hline \multirow[t]{2}{*}{ Unjuk Kerja } & Performa & $\begin{array}{l}\text { Sistem menyediakan cookies, dapat dijalankan diberbagai } \\
\text { sistem operasi dan browser, kemudahan dalam perbaikan } \\
\text { kesalahan }\end{array}$ \\
\hline & Keamanan & $\begin{array}{l}\text { Sistem memberikan peringatan terkait data-data yang } \\
\text { dimasukkan, username menggunakan nim, reset melalui } \\
\text { surat elektronik. }\end{array}$ \\
\hline
\end{tabular}

Sistem Informasi Administasi Program Studi P. TIK yang akan dibangun memiliki tiga bagian utama yaitu bagian staf, mahasiswa, dan dosen. Adapun struktur lebih lengkap dari sistem informasi ini dapat dilihat pada gambar 3 berikut ini.

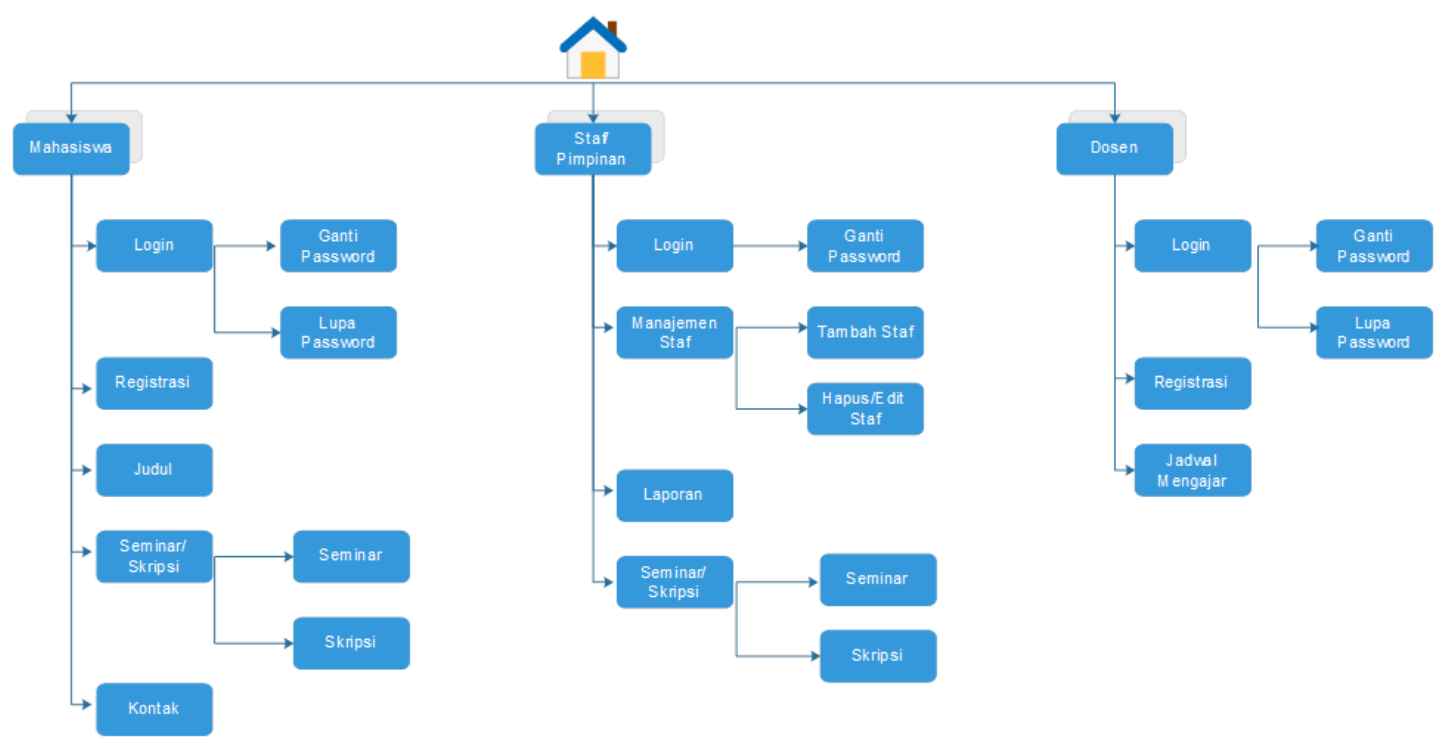

Gambar 3. Struktur Lengkap Sistem Informasi Administrasi Program Studi P.TIK 


\section{Simpulan}

Berdasarkan hasil penelitian dan pembahasan dari penelitian ini, maka dapat ditarik kesimpulan bahwa: 1) sistem informasi Administrasi Program Studi P.TIK IKIP-PGRI Pontianak dibangun untuk melayani kegiatan administrasi Program Studi P.TIK yang terdiri dari: seminar dan skripsi, Jurnal Dosen, Surat Masuk dan Keluar, dan Laporan dengan memperhatikan kebutuhan fungsional, kebutuhan antarmuka, dan kebutuhan unjuk kerja. Untuk kebutuhan fungsional sistem informasi perlu memperhatikan kemudahan dalam memasukkan data, fleksibilitas yang tinggi, dan penyimpanan dengan format yang umum digunakan. Untuk kebutuhan antarmuka sistem informasi dapat diakses dengan menggunakan berbagai perangkat yang memudahkan pengguna dalam memahami sistem informasi. Untuk kebutuhan unjuk kerja sistem perlu memperhatikan keamanan dan protabilitas sistem operasi yang digunakan. 2) Basis data untuk Sistem Informasi Administrasi Program Studi P.TIK IKIP-PGRI Pontianak terdiri dari 16 entitas dan 8 relasi. Entitas pada Sistem Informasi Administrasi Program Studi P.TIK IKIP-PGRI Pontianak yaitu: Mahasiswa, Dosen, Pembimbing, Jenis Pembimbing, Seminar, Kelengkapan Seminar, Penyanggah Mahasiswa, Notulis,Sidang, Kelengkapan Sidang, Skripsi, Jurnal Mengajar, Mata Kuliah, Surat Masuk, Surat Keluar, dan Staf. Adapun relasi untuk masing-masing entitas dalam Sistem Informasi Administrasi Program Studi P.TIK IKIP-PGRI Pontianak yaitu: Bimbingan dengan pembimbing, Melakukan Pembimbingan, Menyanggah seminar, melakukan seminar, Memiliki skripsi, Melakukan siding, Menguji siding, dan Memiliki jurnal mengajar. 3) Aliran data pada Sistem Informasi Administrasi Program Studi P.TIK IKIP-PGRI Pontianak dibagi menjadi dua entitas yaitu mahasiswa dan staf. Mahasiswa memiliki enam aliran masuk dan aliran keluar, sedangkan staf memiliki sepuluh aliran masuk dan aliran keluar. Aliran data pada mahasiswa yaitu: registrasi, login, mahasiswa, judul, seminar, dan skripsi. Adapun aliran data pada staf yaitu login, dosen, pembimbing, seminar,siding, staf, kelengkapan seminar, kelengkapan siding, dan jurnal mengajar. 4) Antarmuka pada Sistem Informasi Administrasi Program Studi P.TIK IKIP-PGRI Pontianak dibagi menjadi dua bagian yaitu mahasiswa dan staf. Halaman untuk mahasiswa terdiri dari enam halaman yaitu: halaman awal, halaman registrasi, halaman login, halaman input judul, halaman seminar, danhalaman sidang. Halaman untuk staf terdiri dari tiga halaman yaitu: halaman login, halaman staf, dan halaman pimpinan.

\section{Daftar Pustaka}

Abraham, C., Junglas, I., \& Willis, M. (2010). System Analysis and Design for Service Oriented ArchitectureProjects: A Case Study at the Federal Financial Institutions Examinations Council (FFIEC). Journal of Emerging Trends in Computing and Information Sciences. Volume 2 No. 1, Hal 1-15. ISSN 2079-5407.

Breiter, A. \& Light, D. (2006). Data for School Improvement: Factors for Designing Effective Information Systems to Support Decision-Making in Schools. Educational Technology \& Society, 9(3), 206-217.

Duan, R. \& Zhang, M. (2007). Design of Web-Based Management Information System for Academc Degree \& Graduate Education. Integration and Innovation Orient to E-Society. Volume 2. Hal 218-226.

Kendall, K. E. \& Kendall, J. E.. 2003. Analisis dan Perancangan Sistem. Jakarta : Indeks Gramedia.

Pressman, R. (2010). Software Engineering - A Practicioner's Approach (7th Ed). McGraw-Hill

Permendikbud. (2013). Penerapan Kerangka Kualifikasi Nasional Indonesia Bidang Pendidikan Tinggi.

Simarmata, Janner. 2007. Perancangan Basis Data. Yogyakarta : Andi Offset.

Sukardi. 2012. Metodologi Penelitian Pendidikan. Yogyakarta : Bumi Aksara

Zheng, J., Feng, Y., \& Zhao, Y. (2014). A Unified Modeling Language-Based Design and Application for Library Management Information System. Cybernetics and Information Technologies. Volume 14, Special Issue. Hal. 129-144. ISSN: 13144081 . 